JEL Codes: H71, I2, J61, C25

Keywords: Geographic mobility, higher education, selection bias, subsidy

\title{
The Effect of College Location on Migration of College-Educated Labor
}

\author{
Jeffrey A. Groen \\ Cornell University
}

July 30, 2003

\begin{abstract}
This paper investigates the impact of attending college in a state on the probability of working in the state. I use information on the set of colleges students applied to as a way to account for selection in college-attendance patterns. For two samples of U.S. undergraduate students, I find a modest link between attending college in a state and working in the state. The magnitude of the effect raises doubts that locationchoice considerations alone can justify state merit-scholarship programs, an increasingly popular form of student financial aid.
\end{abstract}

\footnotetext{
${ }^{\dagger}$ Address: Department of Labor Economics, Cornell University, 357 Ives Hall, Ithaca, NY 14853-3901. E-mail: jg277@cornell.edu. Tel: 607-255-7704. Fax:607-255-4496.

*Acknowledgements: I am grateful to John Bound, Julie Cullen, Ron Ehrenberg, Don Heller, Jim Hines, Gabor Kezdi, Yo Nagai, Sarah Turner, Michelle White, and seminar participants at the University of Michigan, the University of Toledo, the Census Bureau, the Bureau of Labor Statistics, and the APPAM Research Conference for helpful comments. I have also benefited from the comments of Larry Marsh and three anonymous referees. I thank the Population Studies Center of the University of Michigan and the Cornell Higher Education Research Institute for financial support, the Mellon Foundation for access to the College and Beyond (C\&B) data, and Doug Mills and Stacy Berg Dale for help with the C\&B data.
} 


\section{Introduction}

Higher education in the United States is financed to a large extent through state governments. Increasingly, states have adopted merit-based scholarship programs as a major source of student financial aid. Since Georgia introduced its HOPE Scholarship in 1993, at least a dozen states have followed with similar programs. ${ }^{1}$ Scholarships are awarded to state residents on the basis of academic achievement, as measured by highschool grades and standardized test scores. They may be used at in-state colleges and universities only, but many cover attendance at private as well as public institutions. ${ }^{2}$

One goal of merit-aid programs is to develop and retain college-educated workers in a state. ${ }^{3}$ This goal is based on two factors. First, evidence from cities suggests that the overall education level of an area increases the wages of all workers in the area (Moretti, 2003) and contributes to economic growth (Glaeser et al., 1995). Also, college graduates earn more and therefore pay higher taxes to the state. Second, academically talented students often attend college outside their home state. ${ }^{4}$ A perception in many states is that talented students leave the state for college and do not return (Schmidt, 1998).

\footnotetext{
${ }^{1}$ As of July 2001, 13 states offered merit scholarships based on the model of Georgia's HOPE Scholarship (Krueger, 2001).

${ }^{2}$ Georgia's HOPE Scholarship covers tuition, fees, and book expenses for qualified Georgia residents attending any public college in Georgia. Students who attend Georgia private colleges may receive a fixed payment comparable to the value of the subsidy at public colleges (\$3,000 in 1999-2000). To qualify for the scholarship, entering freshmen must have graduated from a Georgia high school with at least a "B" average. To retain their scholarship, students must maintain a 3.0 GPA while in college.

${ }^{3}$ For example, Nebraska Governor E. Benjamin Nelson, in proposing a merit-scholarship program for Nebraska, declared: "We can keep our most promising students in Nebraska by giving them an incentive to study here and stay here." (Quoted in Schmidt, 1998.)

${ }^{4}$ Further, this has become more common over time with the geographic integration of the college market (Hoxby, 1997). See also Table 1.
} 
By lowering the relative price of attending in-state institutions, merit-aid programs seek to increase the number of talented students who attend college in the state rather than in other states. Indeed, evidence from Georgia and New Mexico indicates that their programs have been successful in this regard (Dynarski, 2000; Cornwell et al., 2002; Binder and Ganderton, 2002). However, the ultimate impact of these shifts on the workforce of a state depends on whether attending college in a state encourages students to work in the state. For instance, if a scholarship program induces 100 additional students to attend college in the state, how many of them will work in the state in the long run? This paper investigates the impact of attending college in a state on the probability of working in the state. ${ }^{5}$

Beyond merit scholarships, the evidence and methodology presented in the paper are potentially relevant for a variety of state higher-education policies. Generous subsidies in the form of low in-state tuition at public universities operate in a manner similar to merit scholarships to encourage students to attend college in-state rather than out-of-state. ${ }^{6}$ On the flip side, the level of out-of-state tuition influences the decisions of non-residents to attend college in a state. A natural question, addressed here, is the extent to which non-residents' probability of locating in a state is affected by going to college there. More generally, the relative location effects for resident versus non-resident

\footnotetext{
${ }^{5}$ Economists have studied other aspects of the link between interstate migration and state finance of higher education. For example, some have argued that migration of college graduates reduces the incentives for states to invest in the education of their residents (e.g., Hansen and Weisbrod, 1969; Strathman, 1994). That view typically assumes that graduates' location decisions do not depend on aspects of state higher education systems. In contrast, I consider the possibility that the location decisions of college graduates are based in part on where they attended college.

${ }^{6}$ In addition to providing an incentive to attend in-state institutions, states presumably invest in higher education for a number of reasons. Traditional reasons include a belief in the social benefits of education
} 
students are important for understanding relative admission standards at selective public universities (Groen and White, 2003).

This paper is closely related to the analysis of Bound et al. (2003). Both papers share an interest in linking college attendance and location choice of college-educated workers. Their approach frames the analysis at the state level and investigates the impact of increasing college attendance in a state on the stock of college-educated workers in a state. In contrast, my approach frames the analysis at the individual level and investigates the impact for a given student of attending college in a particular state (rather than another state) on the probability of locating in the state after college. While the approaches are complementary in many respects, an advantage of the individual-level approach taken here is the potential to distinguish college flows according to student characteristics (such as ability and residency).

The next section of the paper develops my econometric approach in a discretechoice model explaining the decision to work in a state. I use information on the set of colleges students applied to as a way to account for selection in college-attendance patterns. Section 3 outlines my empirical strategy and describes two longitudinal data sets on students who attended college in the 1970s. Each data set contains information on students' location during high school, the colleges they applied to and attended, and their state of residence 10-15 years after college.

The empirical results, presented in Section 4, point to a modest link between attending college in a state and working in the state. Plainly, students who attended

and an interest in providing equal access to students regardless of their financial circumstances (Fischer, 1990). 
college in a state are more likely to work in the state than are students who applied in the state but attended college in a different state. However, the magnitude of the effect raises doubts that location-choice considerations alone can justify merit-scholarship programs. The translation of additional students to additional college-educated workers in a state is much less than 1-for-1 because the labor market acts to re-sort students across states after college.

\section{Econometric Strategy}

\subsection{Setup}

A starting point for the analysis is the regression equation

$$
Y_{i j}=s_{j}+\beta_{1} H_{i j}+\beta_{2} C_{i j}+\varepsilon_{i j}
$$

where $i$ indexes individuals and $j$ indexes states. The dependent variable indicates the individual's state of residence after college: $Y_{i j}=1$ if person $i$ lives in state $j$, and $Y_{i j}=0$ otherwise. Note that the unit of observation for the regression is an individualstate. Each of the 50 states and the District of Columbia is considered as an alternative for each individual.

On the right-hand side of equation (1), the variable $s_{j}$ is a state-specific constant term, which captures the relative size of states and other factors (such as climate) that vary across states but not across individuals. ${ }^{7}$ Home state (i.e., state of residence before college) is indicated by the variable $H_{i j}$, which equals 1 if state $j$ is individual $i$ 's home state and equals 0 otherwise. Similarly, the variable $C_{i j}$ indicates whether $i$ attended 
college in state $j$. Note that for a given individual, each of the location variables ( $Y_{i j}$, $H_{i j}$, and $C_{i j}$ ) is equal to 1 for one state and equal to zero for the other states.

The parameter of interest is $\beta_{2}$, which measures the effect of attending college in a state on the probability of working in the state. (While my empirical approach allows the college effect to be different for the individual's home state and other states, for simplicity I ignore that distinction at this point.) There are several reasons why attending college in a state would encourage people to take up residence in the state $\left(\beta_{2}>0\right)$. For instance, college brings students into contact with many people who have ties to the state. Also, college allows students to learn about employers in the area and recreational opportunities nearby.

\subsection{The Problem of Selection Bias}

The OLS estimator of $\beta_{2}$ is unbiased if $C_{i j}$ is uncorrelated with $\varepsilon_{i j}$. At first blush, this might seem plausible given that students choose a college based largely on factors that are unrelated to their future location decisions. Such factors include tuition, college quality, and the types of academic programs offered. However, the location of a college is also a salient factor in the choice process. College location relates to climate, recreational opportunities, and distance from friends and family. These considerations are also likely to be involved in the choice of a location after college, which is reflecting in the dependent variable $Y_{i j}$.

\footnotetext{
${ }^{7}$ An alternative would be to include a list of variables representing desirable or undesirable aspects of states. However, using state-specific constant terms is a more comprehensive approach, since they capture the combined effect of a great number of observable and unobservable state characteristics.
} 
For example, students with strong family ties often choose to attend colleges in their home state or nearby states. In the same way, their preferences for remaining close to home also favor nearby locations after college. More generally, students may choose a college located in an area that they are considering for permanent residence (Morgan, 1983). As a result, students who attend college in a state have (on average) a greater degree of initial location preference for the state than do students who attend college in other states.

Therefore, the OLS estimator of $\beta_{2}$ will reflect both the direct effect of college attendance and a selection effect. Formally,

$$
\operatorname{plim}\left(\hat{\beta}_{2}\right)=\beta_{2}+\frac{\operatorname{Cov}\left(C_{i j}, \varepsilon_{i j}\right)}{\operatorname{Var}\left(C_{i j}\right)},
$$

where the effects of the exogenous variables in equation (1) have been netted out of $C_{i j}$ and $\varepsilon_{i j}$. The first term on the right-hand side of equation (2) is the direct effect and the second term is the selection effect. The consideration of location preferences suggests that the selection effect is positive $\left(\operatorname{Cov}\left(C_{i j}, \varepsilon_{i j}\right)>0\right)$, so $\hat{\beta}_{2}$ is an upward-biased estimator for $\beta_{2}$.

\subsection{A Solution}

I would like to isolate the direct effect. Given current practice, the obvious approach is instrumental variables; however, credible instruments are not available. Therefore, I follow an older tradition in econometrics of treating endogeneity as an omitted variable. I use information on the set of colleges students applied to as a way to control for heterogeneous location preferences before they started college. 
The rationale for this approach follows from the source of the selection problem. If location preferences were a factor in college choice, as I have argued above, then location preferences should be revealed in the set of colleges students apply to. Consider an indicator for applying to college in a state: $A_{i j}=1$ if student $i$ applied to at least one college in state $j$, and $A_{i j}=0$ if $i$ did not apply in $j .^{8}$ Adding this variable to the model, the specification for the control-variable model is:

$$
Y_{i j}=s_{j}+\gamma_{1} H_{i j}+\gamma_{2} C_{i j}+\gamma_{3} A_{i j}+v_{i j}
$$

where the effect of college attendance is $\gamma_{2}$. For this specification, I drop students who applied to colleges in only one state, since they provide no identifying information for the model.

A simple example illustrates how this model is identified. Consider two sets of students from Ohio. Each set applies to colleges in Ohio and North Carolina, but one set attends college in Ohio while the other attends college in North Carolina. The effect of college attendance is based on the difference in probability of working in Ohio between the two sets of students. Essentially, students who applied in a state but attended college elsewhere provide a control group for those who attended college in the state.

The asymptotic bias of $\hat{\gamma}_{2}$ is given by

$$
\operatorname{plim}\left(\hat{\gamma}_{2}\right)=\gamma_{2}+\frac{\operatorname{Cov}\left(C_{i j}, v_{i j}\right)}{\operatorname{Var}\left(C_{i j}\right)}
$$

\footnotetext{
${ }^{8}$ The empirical estimates of the college effect are robust to two alternative specifications of the applications information. In the first alternative, I included the share of a student's total applications in a given state. In the second, I distinguished among applications outside a particular state according to whether they are in nearby or distant states.
} 
where the variables in the second term on the right-hand side net out the effects of the exogenous variables, as in equation (2). Therefore, $\hat{\gamma}_{2}$ is unbiased if $\operatorname{Cov}\left(C_{i j}, v_{i j}\right)=0$; that is, given applying in the state, attending college in the state is uncorrelated with location preference for the state. It is likely, however, that this covariance is positive, because location preferences are presumably involved in each stage of the college-choice process. When students apply to colleges in more than one state (and are admitted), their location preferences are one of the factors in their decision about which college to attend. In the context of the example, the set of students who choose North Carolina may have a greater average preference for North Carolina, and vice versa for those who chose Ohio.

This suggests that the control-variable estimator $\left(\hat{\gamma}_{2}\right)$ is also upward biased.

However, it is plausible that the bias is less than that of the simple estimator $\left(\hat{\beta}_{2}\right)$. To see why, consider the distribution of location preferences for an arbitrary state $j$ among a group of students. The control-variable estimator restricts attention to students who applied in state $j$ and thus creates a more homogeneous group with respect to location preferences for state $j$. Therefore, comparisons between students who attended college in the state and those who attended college in another state are less affected by selection bias. So while the possibility of remaining bias means that the estimates represent upper bounds on the true effects, the control-variable estimator is useful because it has less bias than the simple estimator.

\section{Empirical Approach and Data}

\subsection{Empirical Approach}

My empirical approach involves several straightforward additions to the controlvariable model described by equation (3). First, I allow the effect of attending college in 
a state to vary according to whether it is the student's home state or another state. I make this distinction because scholarship rules and college-admissions policies often depend on students' residence status. Formally, this involves adding two interaction terms to equation (3):

$$
Y_{i j}=s_{j}+\gamma_{1} H_{i j}+\gamma_{2} C_{i j}+\gamma_{3}\left(H_{i j} \times C_{i j}\right)+\gamma_{4} A_{i j}+\gamma_{5}\left(H_{i j} \times A_{i j}\right)+v_{i j}
$$

so that the effect of attending college in one's home state is $\gamma_{2}+\gamma_{3}$ and the effect of attending college in another state is $\gamma_{2}$.

Second, I replace the linear specification with a non-linear specification, the conditional logit model (McFadden, 1974). In this model, the probability that individual $i$ works in state $j$ is:

$$
\operatorname{Pr}\left[Y_{i j}=1\right]=\frac{\exp \left(s_{j}+\gamma^{\prime} X_{i j}\right)}{\sum_{k} \exp \left(s_{k}+\gamma^{\prime} X_{i k}\right)},
$$

where $s_{j}+\gamma^{\prime} X_{i j}$ represents the deterministic part of the right-hand side of equation (5). The conditional logit model has two advantages over the linear specification: the predicted probabilities are bounded between 0 and 1, and the probabilities add up to 1 over states for a given individual. Essentially, the conditional logit recognizes the grouped nature of the data (with 51 observations for each individual), while the linear specification does not.

A relative disadvantage of the conditional logit is that the parameters of interest are not simple functions of the model coefficients. I construct the implied effects of college location by comparing predicted probabilities for different groups of students, based on an analogy to the linear model. For this purpose, it is useful to interpret the effects of college location in the linear model as differences of conditional means. 
Define four conditional mean probabilities of working in state $j$ for the combinations of $H_{i j}$ and $C_{i j}$, according to whether state $j$ is student $i$ 's home state and/or college state, as indicated in Figure 1. (Each mean is also conditional on applying to college in the state.) With this notation, define the effect of attending college in one's home state as $\Delta P_{y}=P_{y y}-P_{y n}$ and the effect of attending college in another state as $\Delta P_{n}=P_{n y}-P_{n n}$.

In the linear model, it is easy to show that $\Delta P_{y}$ and $\Delta P_{n}$ are indeed the parameters of interest: $\Delta P_{y}=\gamma_{2}+\gamma_{3}$ and $\Delta P_{n}=\gamma_{2}$. For the conditional logit model, therefore, I construct college effects based on the conditional means. After estimation, I construct $P_{y y}, P_{y n}, P_{n y}$, and $P_{n n}$ for each of the states with colleges in the data set, based on averages of predicted probabilities for relevant observations. Then I construct the implied estimates of $\Delta P_{y}$ and $\Delta P_{n}$ for each state and compute the average of each across states. ${ }^{9}$ I use a weighted average with weights corresponding to the number of students in the sample for each state.

As a final addition to the model, I include a set of variables reflecting purely individual characteristics such as gender and ability. These variables help control for individual differences in the decision to work in a state, over and above the other factors in the model. In the conditional logit framework, these variables cannot enter separately because they don't vary across states for a given individual. ${ }^{10}$ Instead, they must enter as

\footnotetext{
${ }^{9}$ It is necessary to use this two-step method for the conditional logit because $\Delta P_{y}$ and $\Delta P_{n}$ depend on the state-specific constant terms.

${ }^{10}$ To see why, consider the role of gender. Suppose $M_{i}$ is a dummy variable identifying men, we include a term $\varphi M_{i}$ in equation (6), and that $\varphi>0$. This would mean that men are more likely to work in state $\mathrm{j}$. However, men cannot be more likely to work in every state, because they must work in one and only one
} 
interactions with state-specific variables. I interact them with the variables representing home state, college state, and application state. I include the following individual characteristics: gender, ability, type of college attended, marital status, and attainment of a graduate degree.

\subsection{Data}

My analysis involves two data sets. The first is the Mellon Foundation's College and Beyond $(\mathrm{C} \& \mathrm{~B})$ data set, which contains background information and college records for students at 30 selective colleges and universities. The C\&B includes students who entered college in 1951, 1976, and 1989; I focus here on the 1976 cohort. For 32,720 students from this cohort, the $\mathrm{C} \& \mathrm{~B}$ contains college records, including state of residence at the time of admission, SAT scores, and gender. ${ }^{11}$

The Mellon Foundation also surveyed this cohort in 1996 (when they averaged 38 years of age), providing information for 23,573 respondents on current state of residence and applications to other colleges. In particular, the survey asked respondents to list the college where they received their bachelor's degree, their first-choice college, and up to three other colleges they applied to or seriously considered. Consequently, information was collected on a maximum of five colleges per student. The survey also asked about

state. Algebraically, it is easy to show that $\varphi M_{i}$ washes out of equation (6) because it does not vary across states for a given individual.

${ }^{11}$ The information from college records is available for all students who entered the private institutions and for a sample of 2,000 students who entered each of the public institutions. A list of institutions, with their states and sample sizes for the entire 1976 cohort, is in Appendix A. The institutions cover 17 states and are concentrated in the Midwest and Northeast regions. For more detail on the $\mathrm{C} \& \mathrm{~B}$, see Bowen and Bok (1998). 
marital status and attainment of graduate degrees. After restricting attention to those with complete information on all key variables, my sample contains 19,113 students. ${ }^{12}$

Given the selective nature of the C\&B sample, I also produce estimates from a nationally representative sample: the National Longitudinal Study of the High School Class of 1972 (NLS-72). The NLS-72 surveyed students in the spring of 1972 (at the end of their senior year) and five subsequent times between 1973 and 1986. I select students who attended a four-year college or university on a full-time basis in the fall of 1972. The first follow-up survey asked students to list up to three colleges they applied to. I define the home state based on the high school. Post-college location is based on the state of residence as of the fifth and final follow-up survey in 1986, when NLS-72 respondents averaged 32 years of age. ${ }^{13}$ This survey also provided information on marital status and attainment of graduate degrees. My NLS-72 sample covers 2,805 students. ${ }^{14}$

There are key differences in the composition of the C\&B and NLS-72 samples. Nationwide in 1975, 20 percent of students attending 4-year colleges and universities attended college outside their home state, with a greater share among students attending private versus public institutions (Table 1). In the C\&B, 67 percent applied to colleges in more than one state and 59 percent attended college outside their home state (Table 2).

\footnotetext{
${ }^{12}$ I discard records without state of residence or SAT score. (Only ACT scores are available for about 2 percent of the sample. I converted these scores to equivalent SAT scores, using the equipercentile method (Langston, 1987)). I also discard people who attended high school or lived at the time of the survey outside the United States (this applies to less than 2 percent of the sample in each case).

${ }^{13}$ The public-use version of the NLS-72 does not contain respondent location information for the fifth follow-up survey. The National Opinion Research Center, which conducted the survey, provided data on state of residence for 9,973 of the 14,489 respondents to the fifth follow-up.

${ }^{14}$ In order to estimate the conditional logit model on this sample, I had to drop two states from the choice set. As a result, I had to drop 33 students from the sample.
} 
These figures reflect the dominance of selective and private colleges and universities in the C\&B. By contrast, 20 percent of the NLS-72 sample applied to colleges in more than one state and 21 percent attended college outside their home state. A related difference between the samples is the higher average ability of the $\mathrm{C} \& \mathrm{~B}$ sample. The average SAT score (math plus verbal) is 1,187 in the C\&B and 969 in the NLS- $72 .{ }^{15}$

Using data on students who attended college in the 1970s to learn about the potential effects of current policies might be problematic if current students were expected to be substantially different in terms of geographic mobility than students who attended college in the 1970s. However, data from the decennial census indicate no major trends between 1970 and 1990 in two measures of geographic mobility for college graduates aged 33-55. Both the share living outside their state of birth and the share living in a different state than five years earlier are nearly identical in 1970, 1980, and $1990 .^{16}$

The value of the applications information as an indicator of initial location preference can be illustrated with a simple tabulation from the $\mathrm{C} \& \mathrm{~B}$ data. Consider three application categories for a given state $j:(1)$ did not apply in state $j,(2)$ applied in state $j$ and another state, and (3) applied in state $j$ only. If applications were an indicator of location preference, then these categories would reflect increasing preference for state $j$. Indeed, the sample mean probability of working in state $j$ increases with the application

\footnotetext{
${ }^{15}$ National SAT distributions for 1977 from the Educational Testing Service provide some context for this comparison. The national average combined SAT score was 900 . The average SAT score of 1,187 in the C\&B falls at the 88th percentile of the national distribution, while the average of 969 in the NLS-72 falls at the 62 nd percentile.
} 
variable for each of the four home/college categories (Table 3). For example, for students who attended college in their home state (first column), the probability of working in their home state 15 years after college is 0.46 if they applied outside their home state and 0.58 if they applied only in their home state.

\section{Results}

\subsection{Main Results}

The main results for the $\mathrm{C} \& \mathrm{~B}$ sample are indicated in Table 4. I construct the preferred specification in a sequence of steps. As a starting point, I consider a specification without controls for applications information and individual characteristics. These simple estimates, shown in the first row of Table 4, suggest that college effects are substantial: those who attended college in a state are much more likely to work in the state 15 years after college than are those who attended college in another state. For students who were initially residents of the state, 54 percent of those who attended college in the state ended up working there, compared to 35 percent of those who attended college in another state. For students who were initially non-residents of the state, the corresponding figures are 11 percent and 2 percent. $^{17}$

However, these simple comparisons overstate the true effects of college location because they ignore selection. In contrast, the control-variable model attempts to account for selection by including information on applications. This model involves two changes

\footnotetext{
${ }^{16}$ The share living outside their state of birth at the time of the census is about 52 percent in 1970, 1980, and 1990. The share living in a different state than five years earlier is about 14 percent in 1970, 1980, and 1990.

${ }^{17}$ The comparatively low levels for non-residents reflect the fact that, for a given student, there are 50 "other" states but only one home state.
} 
to the simple model: restricting the sample to students who applied in more than one state and adding a variable for applying in the state $\left(A_{i j}\right)$.

To illustrate the relative importance of each change, I extend the simple model in two steps. First, I restrict the sample to students who applied in more than one state and re-estimate the simple model. As shown in the second row of Table 4, this sample restriction alone reduces the estimated effects, because students who applied in only one state have strong preferences for those states. Second, I add the application variable. This change further reduces the estimated effects, as shown in the third row of Table 4.

Finally, I complete the control-variable model by adding a set of individual characteristics, such as gender and ability, via interaction terms with the variables representing home state, college state, and application state. (Details on these individual characteristics, as well as estimates that vary by sub-group, are given in Section 4.2.) This addition has only a small effect on the results. According to the point estimates for this preferred specification, the average impact of attending college in one's home state is 9 percentage points ( 0.48 vs. 0.39$)$ and the impact of attending college in another state is 6 percentage points $(0.11$ vs. 0.05$)$.

The corresponding results for the NLS-72 sample, based on the same sequence of specifications, are given in Table 5. The results for the preferred specification, shown in the fourth row, suggest that the impact of attending college in one's home state is 10 percentage points - similar to the estimate from the C\&B sample. The NLS-72 students are more likely to work in their home state after college than are the C\&B students, but the impact of attending college in the state is similar for both samples. Turning to the 
impact of attending college in another state, the estimate from the NLS-72 is 10

percentage points, roughly twice the estimate from the C\&B.

One way to compare the results from the C\&B and NLS-72 samples is in the context of a student attending college outside her home state. Based on the $\mathrm{C} \& \mathrm{~B}$ results, her decision decreases the probability of working in her home state by 9 percentage points and increases the probability of working in her college state by 6 percentage points. The remaining 3 percentage points represent an increase in the probability of working in the other 49 states. With the NLS- 72 results, by contrast, the home-state and other-state college effects are identical, so her decision leads to a transfer of 10 percentage points from the probability of working in her home state to the probability of working in her college state, with the probability of working in the other states unchanged.

\subsection{Variation with Individual Characteristics}

Next, I explore variation in the college effect by a variety of individual characteristics. I use the preferred specification from the previous section. However, instead of averaging the predicted probabilities over students of all types, I construct separate estimates for different sub-groups based on the characteristics. I consider variation in the effects by college type, student ability, attainment of advanced degrees, marital status, and gender. I report results for the C\&B sample only, since the NLS-72 sample is too small to allow precise estimates for a further level of detail.

Results are shown in Table 6. Among the three types of institutions in the $\mathrm{C} \& \mathrm{~B}$ sample, the estimated college effects are larger for public universities than for private universities, and larger for private universities than for private colleges. For example, the 
estimated effect of attending college in one's home state varies from 15 percentage points for public universities to zero for private colleges. The larger effect for public universities may result from the higher proportion of in-state students, since the average student is more likely to meet students who already have ties to the state. Among private institutions, the effects may be larger for universities than colleges because universities are typically located in urban areas and represent a larger part of state economies.

For student ability, I construct three categories based on combined SAT scores, with roughly one-third of the full sample in each category. The results reveal an interesting pattern by SAT category for the effect of attending college in one's home state. Figure 2 plots the predicted probability of working in one's home state by SAT category, separately for students who attended college in their home state (top line) and students who attended college in another state (bottom line). For each group, the probability declines monotonically with SAT category. Presumably, this pattern reflects that higher ability students are more likely to participate in regional or national labor markets.

However, the effect of attending college in one's home state does not decline with SAT category. For a given SAT category, the college effect $\left(\Delta P_{y}\right)$ is shown in Figure 2 by the vertical distance between the top line and the bottom line. The estimated effect is smallest for the middle category and largest for the highest category. Overall, these patterns suggest that targeting state scholarships to high-ability students may not be a bad idea, despite their lower probability of remaining in the state. They also explain why the home-state college effects are similar in the C\&B and NLS-72 samples, despite the higher SAT scores of the C\&B sample. 
The comparison of students with an advanced degree and those without is similar to the comparison by SAT category. More than half of the C\&B sample had attained a Master's, Professional, or Doctoral degree by 1996. However, the estimated college effects are not substantially different for those with advanced degrees. Notably, those with advanced degrees are less likely to work in their home state, but the effect of attending college in one's home state is similar to that for students without advanced degrees. ${ }^{18}$ Turning to the other results in Table 6 , the home-state college effect is lower for those who were unmarried as of 1996 than for those who were married, but the otherstate college effect is similar for both groups. The estimated effects are similar for men and women.

\section{Conclusion}

The empirical evidence in this analysis points to a modest link between attending college in a state and working in the state. Even though the estimated impact of college attendance is statistically significant, the magnitude of the impact is rather small, especially given its upward bias. This can be seen in the context of state meritscholarship programs that subsidize attendance in a state as a way to induce college graduates to work in the state. Suppose that a $\$ 1,000$ scholarship induces 100 additional students to attend college in-state rather than out-of-state. The results suggest that no more than 10 of them would be working in the state $10-15$ years after college. The translation of additional students to additional college graduates working in the state is much less than 1-for-1 because the labor market acts to re-sort students across states after

\footnotetext{
${ }^{18}$ I do not attempt to relate the location of the graduate institution to the location of the undergraduate institution. I simply identify whether students earned an advanced degree.
} 
college graduation. Thus the mobility of college graduates across states limits the effectiveness of merit-scholarship programs.

Therefore, it is doubtful that location-choice considerations alone can justify merit-scholarship programs in the model of Georgia's HOPE Scholarship. Policymakers have argued that these programs would allow their states to better retain college-educated workers. However, the modest impacts found in this analysis suggest that other considerations are driving the popularity of merit-scholarship programs. In fact, these programs may be justified primarily by politics rather than economics. The role of politics is suggested by the fact that the scholarships are available to state residents (i.e., voters) only. Furthermore, since the scholarships have no income restrictions, most of the aid goes to students who would have gone to college anyway (Cornwell et al., 2002).

Viewed another way, if the primary motivation for merit-scholarship programs is in fact to encourage college graduates to work in the state, alternative policies might be more cost-effective at achieving that goal. In contrast to the indirect approach of simply encouraging college attendance in a state, some state scholarship programs take a more direct approach by linking aid to working in the state after graduation. For instance, recipients of Maryland's Science and Technology Scholarship must work full-time in Maryland after graduation a year for each year they receive the award, or else repay the scholarship. These programs appear to be more cost-effective because recipients have a financial incentive to work in the state after graduation. ${ }^{19}$

\footnotetext{
${ }^{19}$ In evaluating these programs, a key issue is their ultimate impact on recipients' location choice, since the conditional nature of the aid may attract only those who wish to work in the state in the first place.
} 
More generally, the analysis in this paper raises other questions regarding merit scholarships. For instance, how do the scholarships influence the level and composition of enrollment, in the state overall and at particular institutions? In the short run, institutions may not be able to increase capacity to accommodate the increased demand among state residents. As a result, changes in composition (by ability and residency) may be the major story. ${ }^{20}$ In this regard, the requirements for obtaining the scholarship appear to be important in influencing the changes in composition. In the longer run, institutions may increase capacity so that the major change is in overall college enrollment in the state.

\footnotetext{
${ }^{20}$ In Georgia, the HOPE Scholarship has allowed the University of Georgia to raise its admissions standards, as high-ability Georgia residents switched from attending out-of-state colleges. As a result, some Georgia residents who have been crowded out of the University of Georgia by the increasing standards have enrolled in large public universities in other states (Cornwell et al., 2002).
} 


\section{Appendix A}

\section{Institutions in the College and Beyond Data Set Sample Sizes for the 1976 Cohort}

\begin{tabular}{l} 
Institution \\
\hline Public Universities \\
Miami University \\
University of Michigan (Ann \\
University of North Carolina \\
Pennsylvania State University \\
All \\
Private Universities \\
Columbia University \\
Duke University \\
Emory University \\
Georgetown University \\
Northwestern University \\
University of Notre Dame \\
University of Pennsylvania \\
Princeton University \\
Rice University \\
Stanford University \\
Tufts University \\
Tulane University \\
Vanderbilt University \\
Washington University \\
Yale University \\
All \\
Private Liberal-Arts Colleges \\
Barnard College \\
Bryn Mawr College \\
Denison University \\
Hamilton College \\
Kenyon College \\
Oberlin College \\
Smith College \\
Swarthmore College \\
Wellesley College \\
Wesleyan University \\
Williams College \\
All \\
\hline
\end{tabular}

Ohio

State

Michigan

2,027

North Carolina

1,990

Pennsylvania

New York

726

North Carolina

1,653

Georgia

437

District of Columbia

1,259

Illinois

1,731

Indiana

1,757

Pennsylvania

1,994

New Jersey

1,105

Texas

633

California

1,567

Massachusetts $\quad 1,029$

Louisiana $\quad 1,346$

Tennessee $\quad 1,269$

Missouri $\quad 1,057$

Connecticut

1,302

18,856

$\begin{array}{lr}\text { New York } & 444 \\ \text { Pennsylvania } & 466 \\ \text { Ohio } & 604 \\ \text { New York } & 435 \\ \text { Ohio } & 429 \\ \text { Ohio } & 748 \\ \text { Massachusetts } & 773 \\ \text { Pennsylvania } & 337 \\ \text { Massachusetts } & 589 \\ \text { Connecticut } & 567 \\ \text { Massachusetts } & 493 \\ & 5,885\end{array}$

32,720
444

66

604

435

429

748

773

337

589

567

5,885

All institutions

Source: Bowen and Bok (1998, Table A.1).

Note: The sample sizes reported in the table represent the number of students in the institutional file. The sample used in the paper is smaller because some students with records in the institutional file had missing data or did not complete the post-college survey. 


\section{References}

Binder, M., Ganderton, P.T., 2002. Musical chairs in higher education: incentive effects of a merit-based state scholarship program. Working Paper, University of New Mexico.

Bound, J., Groen, J., Kezdi, G., Turner, S., 2003. Trade in university training: cross-state variation in the production and use of college-educated labor. Journal of Econometrics, this issue.

Bowen, W.G., Bok, D., 1998. The Shape of the River: Long-Term Consequences of Considering Race in College and University Admissions (Princeton University Press, Princeton, New Jersey).

Cornwell, C.M., Mustard, D.B., Sridhar, D.J., 2002. Enrollment effects of merit aid: evidence from Georgia's HOPE Scholarship program. Working Paper, University of Georgia.

Dynarski, S., 2000. Hope for whom? Financial aid for the middle class and its impact on college attendance. National Tax Journal 53, 629-661.

Fischer, F.J., 1990. State financing of higher education: a new look at an old problem. Change 22, 42-56.

Glaeser, E.L., Scheinkman, J.A., Shleifer, A., 1995. Economic growth in a cross-section of cities. Journal of Monetary Economics 36, 117-143.

Groen, J.A., White, M.J., 2003. In-state versus out-of-state students: the divergence of interest between public universities and state governments. National Bureau of Economic Research Working Paper No. 9603. Journal of Public Economics, forthcoming.

Hansen, W.L., Weisbrod, B.A., 1969. Benefits, Costs, and Finance of Public Higher Education (Markham Publishing Company, Chicago).

Hoxby, C.M., 1997. How the changing market structure of U.S. higher education explains college tuition. National Bureau of Economic Research Working Paper No. 6323.

Krueger, C., 2001. Merit scholarships. Education Commission of the States, Denver, Colorado.

Langston, I.W., 1987. SAT-ACT equivalents. Research Memorandum 87-4, University Office of School and College Relations, University of Illinois.

McFadden, D., 1974. Conditional logit analysis of qualitative choice behavior, in: P. Zarembka, ed., Frontiers of Econometrics (Academic Press, New York) 105-142. 
Moretti, E., 2003. Estimating the social return to higher education: evidence from longitudinal and repeated cross-sectional data. Journal of Econometrics, this issue.

Morgan, J.N., 1983. Tuition policy and the interstate migration of college students. Research in Higher Education 19, 183-195.

Ruggles, S., Sobek, M., et al., 1997. Integrated Public Use Microdata Series: Version 2.0 (Historical Census Projects, University of Minnesota, Minneapolis).

Schmidt, P., 1998. More states try to stanch 'brain drains,' but some experts question the strategy. Chronicle of Higher Education, 20 February, A36.

Strathman, J.G., 1994. Migration, benefit spillovers and state support of higher education. Urban Studies 31, 913-920.

U.S. Bureau of the Census, 1980. Census of Population and Housing, Public-Use Microdata ('A' sample): 5-Percent Sample [computer file].

U.S. Department of Education, 1981. Residence and Migration of College Students [computer file].

, 1988. Residence of First-Time Students [computer file]. , 1996. Fall Enrollment Survey [computer file].

, 1999. National Longitudinal Study of the Class of 1972 [computer file]

(National Opinion Research Center, Chicago [producer]; Inter-university Consortium for Political and Social Research, Ann Arbor, Mich. [distributor]).

U.S. Department of Health, Education, and Welfare, 1975. Residence and Migration of College Students [computer file]. 


\section{Table 1}

Share of Students Attending College outside their Home State

\begin{tabular}{lllll} 
& 1975 & 1981 & 1988 & 1996 \\
\hline All & 0.20 & 0.21 & 0.24 & 0.25 \\
Public Institutions & 0.10 & 0.12 & 0.14 & 0.14 \\
Private Institutions & 0.38 & 0.39 & 0.45 & 0.42 \\
\hline
\end{tabular}

Source: Residence and Migration Surveys, U.S. Department of Education.

Note: Data refer to first-time undergraduates at 4-year colleges and universities, excluding students from foreign countries, students in colleges in U.S. territories, and students at military schools. 


\section{Sample Means, C\&B and NLS-72 Samples}

\begin{tabular}{|c|c|c|c|c|}
\hline & \multicolumn{2}{|c|}{ C\&B Sample } & \multicolumn{2}{|c|}{ NLS-72 Sample } \\
\hline & All & $\begin{array}{l}\text { Applied in } \\
\text { More Than } \\
\text { One State }\end{array}$ & All & $\begin{array}{l}\text { Applied in } \\
\text { More Than } \\
\text { One State }\end{array}$ \\
\hline Combined SAT Score & 1,187 & 1,211 & 969 & 1,033 \\
\hline Attended College outside of Home State & 0.59 & 0.75 & 0.21 & 0.55 \\
\hline Public College/University & 0.26 & 0.14 & 0.71 & 0.54 \\
\hline Private College/University & 0.74 & 0.86 & 0.29 & 0.46 \\
\hline Applied to One State & 0.33 & - & 0.80 & - \\
\hline Applied to Two States & 0.25 & 0.38 & 0.14 & 0.71 \\
\hline Applied to Three States & 0.24 & 0.36 & 0.06 & 0.29 \\
\hline Applied to Four or Five States & 0.18 & 0.26 & - & - \\
\hline Number of Students & 19,113 & 12,781 & 2,805 & 547 \\
\hline
\end{tabular}

Note: SAT scores are missing for some students in the NLS-72 sample $(15 \%$ overall and $9 \%$ of students who applied in more than one state). The mean SAT scores reported in the table are for students with nonmissing scores. 
Table 3

\section{Applications and Initial Location Preference, C\&B Sample}

\begin{tabular}{|c|c|c|c|c|}
\hline \multirow{2}{*}{$\begin{array}{l}\text { Application Category } \\
\text { for State } \mathrm{j}\end{array}$} & \multicolumn{2}{|c|}{ Home $=\mathrm{j}$} & \multicolumn{2}{|c|}{ Home $\neq \mathrm{j}$} \\
\hline & College $=\mathrm{j}$ & College $\neq \mathrm{j}$ & College $=\mathrm{j}$ & College $\neq \mathrm{j}$ \\
\hline Did not Apply in State $\mathrm{j}$ & - & 0.31 & - & 0.01 \\
\hline $\begin{array}{l}\text { Applied in State } \mathrm{j} \text { and } \\
\text { another State }\end{array}$ & 0.46 & 0.37 & 0.10 & 0.05 \\
\hline Applied in State j only & 0.58 & - & 0.12 & - \\
\hline
\end{tabular}

Note: For each category, the table shows the sample mean probability of working in state j. Since attendance requires application, some cells are blank. 
Table 4

Effect of College Location, C\&B Sample

\begin{tabular}{|c|c|c|c|c|c|c|c|c|}
\hline \multicolumn{2}{|c|}{ Model } & \multirow[b]{2}{*}{ Sample } & \multicolumn{3}{|c|}{ Home State } & \multicolumn{3}{|c|}{ Other State } \\
\hline $\begin{array}{c}\text { Application } \\
\text { Controls }\end{array}$ & $\begin{array}{c}\text { Individual } \\
\text { Controls }\end{array}$ & & $P_{y y}$ & $P_{y n}$ & $\Delta P_{y}$ & $P_{n y}$ & $P_{n n}$ & $\Delta P_{n}$ \\
\hline No & No & All & 0.54 & 0.35 & $\begin{array}{c}0.19 \\
(0.005)\end{array}$ & 0.11 & 0.02 & $\begin{array}{c}0.09 \\
(0.001)\end{array}$ \\
\hline No & No & $\begin{array}{l}\text { Applied in } \\
\text { More Than } \\
\text { One State }\end{array}$ & 0.47 & 0.34 & $\begin{array}{c}0.13 \\
(0.005)\end{array}$ & 0.10 & 0.02 & $\begin{array}{c}0.08 \\
(0.001)\end{array}$ \\
\hline Yes & No & $\begin{array}{l}\text { Applied in } \\
\text { More Than } \\
\text { One State }\end{array}$ & 0.49 & 0.39 & $\begin{array}{c}0.10 \\
(0.004)\end{array}$ & 0.10 & 0.05 & $\begin{array}{c}0.05 \\
(0.001)\end{array}$ \\
\hline Yes & Yes & $\begin{array}{l}\text { Applied in } \\
\text { More Than } \\
\text { One State }\end{array}$ & 0.48 & 0.39 & $\begin{array}{c}0.09 \\
(0.009)\end{array}$ & 0.11 & 0.05 & $\begin{array}{c}0.06 \\
(0.003)\end{array}$ \\
\hline
\end{tabular}

Notes: Results are based on conditional logit models. Sample sizes are 19,113 students for first row and 12,781 students for the other rows. Standard errors are in parentheses. 


\section{Table 5}

Effect of College Location, NLS-72 Sample

\begin{tabular}{|c|c|c|c|c|c|c|c|c|}
\hline \multicolumn{2}{|c|}{ Model } & \multirow[b]{2}{*}{ Sample } & \multicolumn{3}{|c|}{ Home State } & \multicolumn{3}{|c|}{ Other State } \\
\hline $\begin{array}{c}\text { Application } \\
\text { Controls }\end{array}$ & $\begin{array}{c}\text { Individual } \\
\text { Controls }\end{array}$ & & $P_{y y}$ & $P_{y n}$ & $\Delta P_{y}$ & $P_{n y}$ & $P_{n n}$ & $\Delta P_{n}$ \\
\hline No & No & All & 0.73 & 0.45 & $\begin{array}{c}0.28 \\
(0.010)\end{array}$ & 0.17 & 0.01 & $\begin{array}{c}0.16 \\
(0.005)\end{array}$ \\
\hline No & No & $\begin{array}{l}\text { Applied in } \\
\text { More Than } \\
\text { One State }\end{array}$ & 0.60 & 0.44 & $\begin{array}{c}0.16 \\
(0.027)\end{array}$ & 0.14 & 0.01 & $\begin{array}{c}0.13 \\
(0.008)\end{array}$ \\
\hline Yes & No & $\begin{array}{l}\text { Applied in } \\
\text { More Than } \\
\text { One State }\end{array}$ & 0.62 & 0.51 & $\begin{array}{c}0.11 \\
(0.024)\end{array}$ & 0.15 & 0.04 & $\begin{array}{c}0.11 \\
(0.008)\end{array}$ \\
\hline Yes & Yes & $\begin{array}{l}\text { Applied in } \\
\text { More Than } \\
\text { One State }\end{array}$ & 0.62 & 0.52 & $\begin{array}{c}0.10 \\
(0.028)\end{array}$ & 0.15 & 0.05 & $\begin{array}{c}0.10 \\
(0.016)\end{array}$ \\
\hline
\end{tabular}

Notes: Results are based on conditional logit models. Sample sizes are 2,805 students for first row and 547 students for the other rows. Standard errors are in parentheses. 


\section{Table 6}

\section{Effect of College Location, by Individual Characteristics, C\&B Sample}

\begin{tabular}{|c|c|c|c|c|c|c|c|}
\hline & \multirow{2}{*}{$\begin{array}{c}\text { Sample } \\
\text { Share }\end{array}$} & \multicolumn{3}{|c|}{ Home State } & \multicolumn{3}{|c|}{ Other State } \\
\hline & & $P_{y y}$ & $P_{y n}$ & $\Delta P_{y}$ & $P_{n y}$ & $P_{n n}$ & $\Delta P_{n}$ \\
\hline \multicolumn{8}{|l|}{ College Type: } \\
\hline Public Univ. & 0.14 & 0.49 & 0.34 & $\begin{array}{c}0.15 \\
(0.009)\end{array}$ & 0.16 & 0.04 & $\begin{array}{c}0.12 \\
(0.008)\end{array}$ \\
\hline Private Univ. & 0.64 & 0.43 & 0.34 & $\begin{array}{c}0.09 \\
(0.008)\end{array}$ & 0.09 & 0.04 & $\begin{array}{c}0.05 \\
(0.002)\end{array}$ \\
\hline Private College & 0.22 & 0.34 & 0.34 & $\begin{array}{c}0.00 \\
(0.012)\end{array}$ & 0.07 & 0.04 & $\begin{array}{c}0.03 \\
(0.003)\end{array}$ \\
\hline \multicolumn{8}{|l|}{ SAT Score: } \\
\hline Low & 0.26 & 0.52 & 0.44 & $\begin{array}{c}0.08 \\
(0.011)\end{array}$ & 0.09 & 0.05 & $\begin{array}{c}0.04 \\
(0.004)\end{array}$ \\
\hline Middle & 0.34 & 0.47 & 0.41 & $\begin{array}{c}0.06 \\
(0.009)\end{array}$ & 0.11 & 0.05 & $\begin{array}{c}0.06 \\
(0.003)\end{array}$ \\
\hline High & 0.40 & 0.44 & 0.33 & $\begin{array}{c}0.11 \\
(0.008)\end{array}$ & 0.11 & 0.05 & $\begin{array}{c}0.06 \\
(0.002)\end{array}$ \\
\hline \multicolumn{8}{|l|}{ Advanced Degree: } \\
\hline Yes & 0.59 & 0.45 & 0.36 & $\begin{array}{c}0.09 \\
(0.009)\end{array}$ & 0.10 & 0.05 & $\begin{array}{c}0.05 \\
(0.002)\end{array}$ \\
\hline No & 0.41 & 0.52 & 0.43 & $\begin{array}{c}0.09 \\
(0.010)\end{array}$ & 0.11 & 0.05 & $\begin{array}{c}0.06 \\
(0.004)\end{array}$ \\
\hline \multicolumn{8}{|l|}{ Marital Status: } \\
\hline Married & 0.80 & 0.48 & 0.37 & $\begin{array}{c}0.11 \\
(0.008)\end{array}$ & 0.11 & 0.05 & $\begin{array}{c}0.06 \\
(0.003)\end{array}$ \\
\hline Unmarried & 0.20 & 0.46 & 0.43 & $\begin{array}{c}0.03 \\
(0.013)\end{array}$ & 0.10 & 0.05 & $\begin{array}{c}0.05 \\
(0.004)\end{array}$ \\
\hline \multicolumn{8}{|l|}{ Gender: } \\
\hline Men & 0.53 & 0.50 & 0.39 & $\begin{array}{c}0.11 \\
(0.008)\end{array}$ & 0.10 & 0.05 & $\begin{array}{c}0.05 \\
(0.002)\end{array}$ \\
\hline Women & 0.47 & 0.46 & 0.38 & $\begin{array}{c}0.08 \\
(0.010) \\
\end{array}$ & 0.12 & 0.06 & $\begin{array}{c}0.06 \\
(0.003) \\
\end{array}$ \\
\hline
\end{tabular}

Notes: Results are based on conditional logit model with controls for applications and individual characteristics. The sample is students who applied in more than one state $(\mathrm{N}=12,781)$. Standard errors are in parentheses. For a list of institutions in the C\&B, by college type, see Appendix A. SAT categories are 400-1120 (low), 1120-1265 (middle), and 1265-1600 (high). Marital status and advanced degree are as reported in 1996. Advanced degree is defined as having a Master's, Professional, or Doctoral degree. In the estimates by college type, the values of $P_{y n}$ and $P_{n n}$ are predicted probabilities averaged across all college types, since a given student often applies to more than one type of college. 


\section{Figure 1}

Notation for Conditional Means and College Effect

\begin{tabular}{|c|c|c|c|}
\hline \multirow[b]{2}{*}{ Home State } & \multicolumn{2}{|c|}{ College State } & \multirow[b]{2}{*}{ College Effect } \\
\hline & $C_{i j}=1$ & $C_{i j}=0$ & \\
\hline$H_{i j}=1$ & $P_{y y}$ & $P_{y n}$ & $\Delta P_{y}=P_{y y}-P_{y n}$ \\
\hline$H_{i j}=0$ & $P_{n y}$ & $P_{n n}$ & $\Delta P_{n}=P_{n y}-P_{n n}$ \\
\hline
\end{tabular}

Note: The $P_{a b}$ terms represent the probability of working in state $\mathrm{j}$, depending on whether state $\mathrm{j}$ is student i's home state and/or college state. The first subscript indicates whether state $\mathrm{j}$ is the home state (' $\mathrm{y}$ ' for yes) or not ('n' for no) and the second subscript similarly refers to whether the state $\mathrm{j}$ is the college state. 


\section{Figure 2}

Probability of Working in Home State, by SAT Category and College Location C\&B Sample

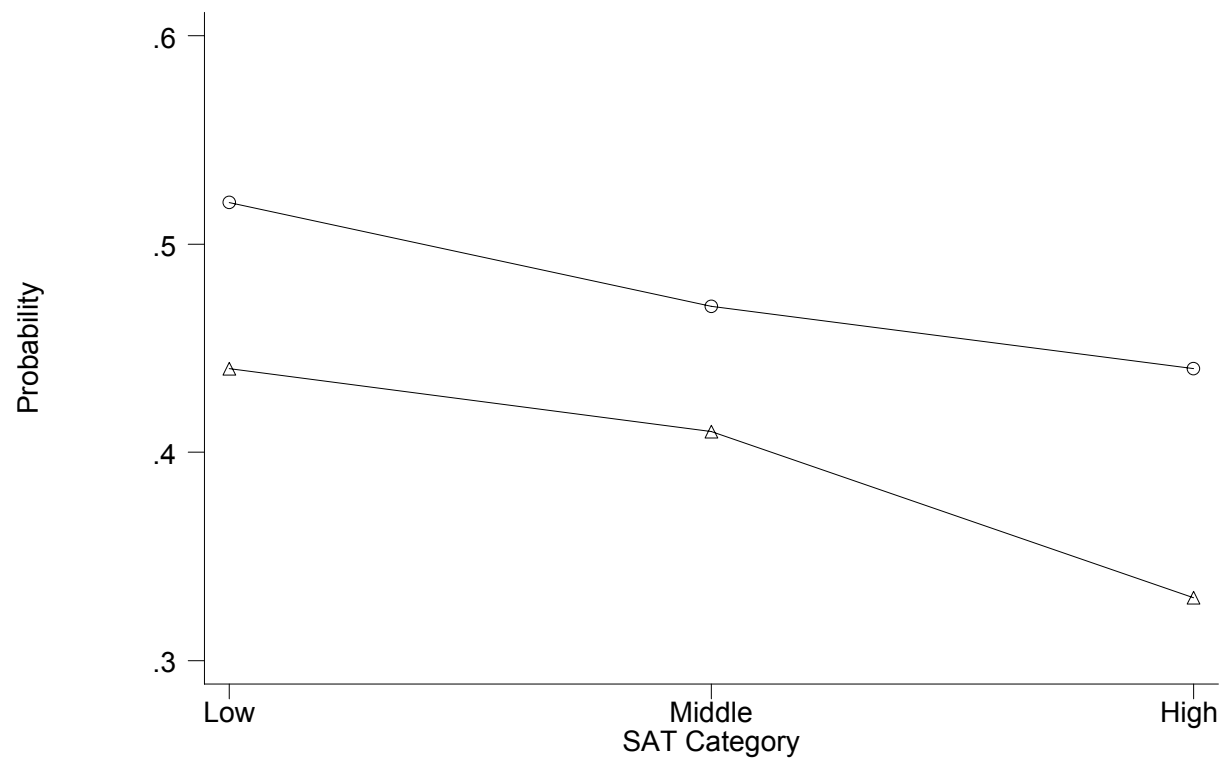

Notes: Figure shows predicted probabilities based on conditional logit model with controls for applications and individual characteristics. The sample is students who applied in more than one state $(\mathrm{N}=12,781)$. The top line refers to students who attended college in their home state. The bottom line refers to students who attended college in another state. See also Table 6. SAT categories are 400-1120 (low), 1120-1265 (middle), and 1265-1600 (high). 